\title{
Article \\ Uremic Toxin Indoxyl Sulfate Impairs Hydrogen Sulfide Formation in Renal Tubular Cells
}

\author{
Chien-Lin Lu ${ }^{1,2} \mathbb{D}$, Chun-Hou Liao ${ }^{1,3}$, Wen-Bin Wu ${ }^{1} \mathbb{D}$, Cai-Mei Zheng ${ }^{4,5,6} \mathbb{D}$, Kuo-Cheng Lu ${ }^{2,7}$ \\ and Ming-Chieh $\mathrm{Ma}^{1, *}$
}

check for updates

Citation: Lu, C.-L.; Liao, C.-H.; Wu, W.-B.; Zheng, C.-M.; Lu, K.-C.; Ma, M.-C. Uremic Toxin Indoxyl Sulfate Impairs Hydrogen Sulfide Formation in Renal Tubular Cells. Antioxidants 2022, 11, 361. https://doi.org/ 10.3390/antiox11020361

Academic Editors: Emma Mitidieri, Vincenzo Brancaleone and Stanley Omaye

Received: 21 January 2022

Accepted: 8 February 2022

Published: 11 February 2022

Publisher's Note: MDPI stays neutral with regard to jurisdictional claims in published maps and institutional affiliations.

Copyright: (C) 2022 by the authors. Licensee MDPI, Basel, Switzerland This article is an open access article distributed under the terms and conditions of the Creative Commons Attribution (CC BY) license (https:// creativecommons.org/licenses/by/ $4.0 /)$.
1 School of Medicine, College of Medicine, Fu Jen Catholic University, New Taipei City 242062, Taiwan; 096195@mail.fju.edu.tw (C.-L.L.); 065294@mail.fju.edu.tw (C.-H.L.); wenbin@mail.fju.edu.tw (W.-B.W.)

2 Division of Nephrology, Department of Internal Medicine, Fu Jen Catholic University Hospital, Fu Jen Catholic University, New Taipei City 243089, Taiwan; tch33730@tzuchi.com.tw

3 Divisions of Urology, Department of Surgery, Cardinal Tien Hospital, New Taipei City 231403, Taiwan

4 Division of Nephrology, Department of Internal Medicine, Taipei Medical University Shuang Ho Hospital, New Taipei City 235041, Taiwan; 11044@s.tmu.edu.tw

5 Division of Nephrology, Department of Internal Medicine, School of Medicine, College of Medicine, Taipei Medical University, Taipei 110301, Taiwan

6 Research Center of Urology and Kidney, Taipei Medical University, Taipei 110301, Taiwan

7 Division of Nephrology, Department of Medicine, Taipei Tzu Chi Hospital, Buddhist Tzu Chi Medical Foundation, New Taipei City 231405, Taiwan

* Correspondence: med0041@mail.fju.edu.tw

\begin{abstract}
Hydrogen sulfide $\left(\mathrm{H}_{2} \mathrm{~S}\right)$ was the third gasotransmitter to be recognized as a cytoprotectant. A recent study demonstrated that exogenous supplementation of $\mathrm{H}_{2} \mathrm{~S}$ ameliorates functional insufficiency in chronic kidney disease (CKD). However, how the $\mathrm{H}_{2} \mathrm{~S}$ system is impaired by CKD has not been elucidated. The uremic toxin indoxyl sulfate (IS) is known to accumulate in CKD patients and harm the renal tubular cells. This study therefore treated the proximal tubular cells, $\mathrm{LLC}_{\mathrm{PK}}$, with IS to see how IS affects $\mathrm{H}_{2} \mathrm{~S}$ formation. Our results showed that $\mathrm{H}_{2} \mathrm{~S}$ release from LLC-PK cells was markedly attenuated by IS when compared with control cells. The $\mathrm{H}_{2} \mathrm{~S}$ donors $\mathrm{NaHS}$ and GYY-4137 significantly attenuated IS-induced tubular damage, indicating that IS impairs $\mathrm{H}_{2} \mathrm{~S}$ formation. Interestingly, IS downregulated the $\mathrm{H}_{2} \mathrm{~S}$-producing enzymes cystathionine $\beta$-synthase (CBS), cystathionine $\gamma$-lyase (CSE), and 3-mercaptopyruvate sulfurtransferase (3-MST), and these effects could be reversed by inhibition of the IS receptor, aryl hydrocarbon receptor (AhR). As transcription factor specificity protein $1\left(\mathrm{Sp} 1\right.$ ) regulates the gene expression of $\mathrm{H}_{2} \mathrm{~S}$-producing enzymes, we further showed that IS significantly decreased the DNA binding activity of Sp1 but not its protein expression. Blockade of AhR reversed low Sp1 activity caused by IS. Moreover, exogenous $\mathrm{H}_{2} \mathrm{~S}$ supplementation attenuated IS-mediated superoxide formation and depletion of the cellular glutathione content. These results clearly indicate that IS activates AhR, which then attenuates Sp1 function through the regulation of $\mathrm{H}_{2} \mathrm{~S}$-producing enzyme expression. The attenuation of $\mathrm{H}_{2} \mathrm{~S}$ formation contributes to the low antioxidant defense of glutathione in uremic toxin-mediated oxidative stress, causing tubular cell damage.
\end{abstract}

Keywords: chronic kidney disease; hydrogen sulfide; indoxyl sulfate; specificity protein 1; oxidative stress; tubulotoxicity

\section{Introduction}

Hydrogen sulfide $\left(\mathrm{H}_{2} \mathrm{~S}\right)$ is a gaseous intracellular signaling transmitter, like nitric oxide and carbon monoxide. The half-life of $\mathrm{H}_{2} \mathrm{~S}$ in plasma is less than $30 \mathrm{~min}$, and elimination occurs through excretion in exhaled breath [1] or through binding and oxidation by hemoglobin in the circulation (sulfhemoglobin) [2]. $\mathrm{H}_{2} \mathrm{~S}$ can freely move across cell membranes by simple diffusion and does not require a facilitator because its solubility is fivefold 
greater in lipophilic solvents than in water [3]. In mammalians, $\mathrm{H}_{2} \mathrm{~S}$ is synthesized endogenously from L-cysteine through the catalyzation of three major $\mathrm{H}_{2} \mathrm{~S}$-producing enzymes, cystathionine $\beta$-synthase (CBS), cystathionine $\gamma$-lyase (CSE), and 3-mercaptopyruvate sulfurtransferase (3-MST), along with cystathionine aminotransferase (CAT). CBS and CSE are both dominant enzymes for renal $\mathrm{H}_{2} \mathrm{~S}$ generation that are mainly distributed in the proximal tubules and not in the glomerulus or the distal tubules [4]. Compared with CBS and CSE, 3-MST is broadly distributed in the kidneys, including in the proximal tubules, distal tubules, collecting duct, and renal pelvis [5]. As a result, $\mathrm{H}_{2} \mathrm{~S}$ generation is abundant in the renal system and plays an important role in renal physiology. $\mathrm{H}_{2} \mathrm{~S}$ activates ATP-sensitive $\mathrm{K}^{+}$channels and vasodilates the preglomerular arterioles rather than the post-glomerular arterioles, increasing renal blood flow and glomerular filtration rate [6]. Moreover, $\mathrm{H}_{2} \mathrm{~S}$ inhibits tubular $\mathrm{Na}^{+}$transporter activity through pathways such as the $\mathrm{Na}^{+} / \mathrm{K}^{+}$-ATPase and $\mathrm{Na}^{+} / \mathrm{K}^{+} / 2 \mathrm{Cl}^{-}$cotransporters and consequently enhances urinary salt excretion. $\mathrm{H}_{2} \mathrm{~S}$ also upregulates aquaporin-2 expression and trafficking in the inner medulla principal cells, increasing the water permeability of the collection duct and promoting urine concentration [7].

The $\mathrm{H}_{2} \mathrm{~S}$ level along with the level of renal $\mathrm{H}_{2} \mathrm{~S}$-producing enzymes were shown to both significantly reduce in plasma and remnant kidney tissue in a rat model of $5 / 6$ nephrectomyinduced chronic kidney disease (CKD) [8]. When given $\mathrm{NaHS}$ exogenously, an $\mathrm{H}_{2} \mathrm{~S}$ donor can ameliorate gentamicin-induced tubulotoxicity in the renal tubular cells by reducing oxidative stress production and apoptosis. Moreover, treatment with $\mathrm{H}_{2} \mathrm{~S}$ in $\mathrm{CKD}$ rats improves renal function remarkably and alleviates pathological injuries such as tubular dilation and atrophy, interstitial inflammation, and fibrosis [9]. Interestingly, in end-stage renal disease (ESRD), dialysis patients have reduced serum CSE level and $\mathrm{H}_{2} \mathrm{~S}$ production, accompanied by high levels of plasma homocysteine and cysteine, which are the substrates for CSE-induced $\mathrm{H}_{2} \mathrm{~S}$ biosynthesis. This decrease in $\mathrm{H}_{2} \mathrm{~S}$ and subsequent increase in homocysteine are implicated in the pathogenesis of high hypertension prevalence and cardiovascular mortality in dialysis patients [10].

Indoxyl sulfate (IS) is a uremic toxin that accumulates during renal function deterioration. IS exerts its nephrotoxicity effects by directly injuring the renal tubules via transient receptor potential vanilloid 1 (TRPV1) hyperfunction [11] and the induction of the overproduction of transforming growth factor- $\beta 1$, which participates in the formation of interstitial inflammation and renal fibrosis, both of which that eventually contribute to CKD progression. Additionally, IS increases reactive oxygen species (ROS) production through the promotion of NADPH oxidase 4 (NOX4) [12] and also reduces the activity of glutathione and superoxide dismutase, the powerful antioxidants in renal tubular cells [13]. Therefore, IS greatly increases the oxidative burden that harms renal tubular cells and reduces tubular cell viability.

Until now, no studies have addressed how the $\mathrm{H}_{2} \mathrm{~S}$ system is impaired by CKD. We postulate that IS would decrease $\mathrm{H}_{2} \mathrm{~S}$ synthesis, which might cause tubular oxidative damage in the cell model of CKD. To investigate the roles of $\mathrm{H}_{2} \mathrm{~S}$ - and $\mathrm{H}_{2} \mathrm{~S}$-synthesizing enzymes, the present study examined the impact of IS on $\mathrm{H}_{2} \mathrm{~S}$ expression and the subsequent redox alterations in renal tubular cells.

\section{Materials and Methods}

\subsection{Tubular Cell Culture and Drug Treatment}

Because the distal tubules lack the $\mathrm{H}_{2} \mathrm{~S}$-producing enzymes CBS and CSE [4], the present study used Lilly Laboratories cell-porcine kidney 1 (LLC-PK 1 ) cells as a model of proximal tubule cell origin, as previously reported [14]. Our recent study showed that LLC-PK 1 cells are vulnerable to IS [11]. Cells were obtained from the Bioresource Collection and Research Center (Hsinchu, Taiwan). These cell lines were originally derived from the American Type Culture Collection line CL-101 for LLC-PK 1 . All culture media and supplements were purchased from Thermo Scientific HyClone (South Logan, UT, USA). LLC-PK 1 cells were maintained in Medium 199 supplemented with 3\% fetal bovine serum, sodium 
bicarbonate $(1.5 \mathrm{~g} / \mathrm{L})$, penicillin $(10,000 \mathrm{U} / \mathrm{mL})$, and streptomycin $(10,000 \mu \mathrm{g} / \mathrm{mL})$. The cells were cultured in an incubator, $5 \% \mathrm{CO}_{2}$ at $37^{\circ} \mathrm{C}$, relative humidity of $95 \%$. Subculture of cells was conducted every three days or have reached about $80 \%$ confluence. LLC-PK 1 cells and $1 \mathrm{~mL}$ fresh culture medium were added to each well of the 24-well plate for 2 days. In each experiment, $100 \mu \mathrm{L}$ culture medium was sampled to mix with chemical treatment for an indicated concentration.

Cells were treated with vehicle solution $(0.01 \%$ DMSO) or IS $(10 \mathrm{mM})$ for 24,48 , or $72 \mathrm{~h}$. To test the effect of exogenous $\mathrm{H}_{2} \mathrm{~S}$ supplementation, two $\mathrm{H}_{2} \mathrm{~S}$ donors, NaHS (10, 30 , and $100 \mu \mathrm{M})$ and GYY-4137 $(10,30$, and $50 \mu \mathrm{M})$, were treated alone or in combination with IS. To inhibit endogenous $\mathrm{H}_{2} \mathrm{~S}$ formation, a non-selective CBS and CSE blocker, aminooxyacetic acid (AOAA, $100 \mu \mathrm{M})$, was given alone or in combination with IS. A specific aryl hydrocarbon receptor (AhR) antagonist, $\mathrm{CH}-223191(10 \mu \mathrm{M})$, was applied to the IS-treated cells to test whether the inhibition of AhR affects the tubular $\mathrm{H}_{2} \mathrm{~S}$ system. The dosing of each drug was determined by reference to EC50 or IC50. All chemicals were obtained from Sigma-Aldrich (St. Louis, MO, USA).

\subsection{Cytotoxicity Assay}

The cytotoxic effect of cells treated with or without IS were based on the measurement of lactate dehydrogenase (LDH) released from the injured cells using a Cytotoxicity Detecting kit (Roche Applied Science, Mannheim, Germany). The absorbance spectrum of the final reaction mixture was measured at $492 \mathrm{~nm}$ by a standard ELISA reader and LDH concentration was calculated against a standard concentration (Sigma-Aldrich), as previously described [11]. The 3-(4,5)-2,5-diphenyltetrazolium bromide (MTT) assay was used to evaluate the cell viability. At first, treatment with IS alone or in combination with other blockers to LLC-PK 1 cells for $48 \mathrm{~h}$. After removing the culture medium, the cells were washed twice with PBS (pH 7.4). Next, we added $10 \mu \mathrm{L}$ MTT $(5 \mathrm{mg} / \mathrm{mL}, \mathrm{pH}$ 7.4) in each well for $4 \mathrm{~h}$, and the optical density (OD) was immediately measured after incubating at $37^{\circ} \mathrm{C}$. The percentage of cell viability was calculated as follows: viable cells $(\%)=[100 \times$ (treated OD/control OD)], as previously described [11].

\subsection{Measurement of the $\mathrm{H}_{2} \mathrm{~S}$ Level}

After treatment with IS alone or in combination of AOAA, $500 \mu \mathrm{L}$ of cell culture medium was sampled to determine the level of $\mathrm{H}_{2} \mathrm{~S} . \mathrm{H}_{2} \mathrm{~S}$ production was measured using an ion-selective electrode (Lazar Research Laboratories, Los Angeles, CA, USA) on a Fisher Accumet Model $10 \mathrm{pH}$ meter (Fisher Scientific, Pittsburgh, PA, USA) following the manufacturer's directions, as previously described [15]. Standards were prepared from $\mathrm{NaHS}$ solution with a concentration range of 0.1 to $100 \mu \mathrm{M}$.

\subsection{Western Blot Analysis for Protein Expression}

Measurement of the total protein content in the samples was determined by a commercial protein assay kit (Bio-Rad, Hercules, CA, USA). The samples were separated by sodium dodecyl sulfate-polyacrylamide gel electrophoresis (SDS-PAGE) and then electrophoretically transferred onto polyvinylidene difluoride membranes, as previously described [11]. The blotted membrane was blocked in fresh PBS containing 5\% non-fat milk and subsequently incubated the membrane in a primary antibodies solution against CSE, CBS, 3-MST, or specificity protein 1 (Sp1) (Santa Cruz Biotechnology, Santa Cruz, CA, USA) overnight at $4{ }^{\circ} \mathrm{C}$. Next, the membranes were incubated for one hour at room temperature with horseradish peroxidase-conjugated secondary antibody (Jackson ImmunoResearch, West Grove, PA, USA) after rinsing with PBS to remove the unbound antibodies. The visualization of the secondary antibody was performed using an enhanced chemiluminescence procedure (Thermo Scientific, Rockford, IL, USA). 


\subsection{Measurement of Sp1 Activity}

Nuclear extracted proteins were prepared from the tubular cells using a commercial kit (BioVision, Milpitas, CA, USA), as described above, following the manufacturer's instructions. Nuclear proteins $(10 \mu \mathrm{g})$ were used to determine Sp1 activity using a high throughput commercial kit (Abcam, Cambridge, UK). Briefly, a specific double stranded DNA sequence containing the Sp1 consensus binding site (5'-GGGGCGGGG-3') was immobilized onto a 96-well plate. Active Sp1 was labeled in nuclear extract by oligonucleotide specifically binding Sp1. The epitope of Sp1 is recognized by a primary antibody. Hence, Sp1 can only be detected when Sp1 is in active form or bind to its target DNA. Next, secondary antibody conjugated to horseradish peroxidase (HRP) provides the colorimetric readout at O.D. $450 \mathrm{~nm}$.

2.6. Real-Time Quantitative Polymerase Chain Reaction (RT-qPCR) for the Quantification of CBS, CSE, and 3-MST mRNA Expression

Commercial RNA extraction kit (RareRNA, Bio-East Technology, Taipei, Taiwan) was used to isolate cellular RNA, as previously described [11]. The DNase I kit (Invitrogen, Carlsbad, CA, USA) was used to prepare DNA-free RNA solution. In the experiment, $5 \mu \mathrm{g}$ of total RNA as starting material, $5 \mu \mathrm{g}$ of oligo(dT)15 primer (Life Technologies, Carlsbad, CA, USA), and 200 units of reverse transcriptase (Moloney murine leukemia virus; Promega, Madison, WI, USA) were used to synthesize complementary DNA (cDNA) at $42{ }^{\circ} \mathrm{C}$ for $45 \mathrm{~min}$. Real-time quantitative polymerase chain reaction (RT-qPCR) amplification was conducted using a standard TaqMan PCR protocol on ABI StepOnePlus system (Applied Biosystems, Foster City, CA, USA). The primers used for RT-qPCR are listed in Table 1. All samples were tested in duplicate wells. The $\Delta \mathrm{Ct}$ (threshold cycle) was calculated by subtracting of the average glyceraldehyde-3-phosphate dehydrogenase (GAPDH) $\mathrm{Ct}$ values from the target genes $\mathrm{C} t$ values, which reflects the target gene mRNA level. The change of CBS, CSE, and 3-MST gene expression were calculated as $2^{-\Delta C t}$, and the fold change of genes was presented compared to control group.

Table 1. List of primer sequences used for RT-qPCR.

\begin{tabular}{|c|c|c|}
\hline Gene & GenBank Accession Number & Sequence \\
\hline CBS & XM_039080137 & $\begin{array}{c}\text { 5'-TAG ACG GCA GAG CCT TTC } \\
\text { GA-3' (forward) } \\
\text { 5'-AAT CCC CGG CCG TAG } \\
\text { AAC-3' (reverse) }\end{array}$ \\
\hline CSE & NM_017074 & $\begin{array}{l}\text { 5'-ACA CTT CAG GAA TGG GAT } \\
\text { GG-3' (forward) } \\
\text { 5'-TGA GCA TGC TGC AGA GTA } \\
\text { CC-3' (reverse) }\end{array}$ \\
\hline 3-MST & NM_001013440 & $\begin{array}{c}\text { 5'-CTG GGA AAC GGG GAG } \\
\text { CG-3' (forward) } \\
\text { 5'-GCT CGG AAA AGT TGC GGG } \\
-3^{\prime} \text { (reverse) }\end{array}$ \\
\hline GAPDH & XM_039097338 & $\begin{array}{c}\text { 5'-TTA GCA CCC CTG GCC AAG } \\
\text { G-3' (forward) } \\
\text { 5'-CTT ACT CCT TGG AGG CCA } \\
\text { TG-3' (reverse) }\end{array}$ \\
\hline
\end{tabular}

\subsection{Superoxide Formation Examined by Chemiluminescence (CL) Analysis}

The release of superoxide $\left(\mathrm{O}_{2}{ }^{-}\right)$into the culture medium was determined as previously described [16]. After treatment for $48 \mathrm{~h}, 100 \mu \mathrm{L}$ culture medium was harvested from the treated group instantly. The culture medium was stored at $4{ }^{\circ} \mathrm{C}$ in the dark (wrapped in aluminum foil) until measurement. The samples were rinsed with $0.1 \mathrm{~mL}$ of PBS (pH 7.4) before CL measurement. During the analysis, culture medium was kept in a dark room 
in order to detect the emission of photons from CL using Chemiluminescence Analyzing System (CLD-110, Tohoku Electronic Industrial Co., Sendai, Japan). Lucigenin solution $(0.1 \mathrm{mM})$ was prepared in PBS $1.0 \mathrm{~mL}$ and added into the culture medium. The area under the curve (AUC) was used to assess the total CL amount. In each experiment, a duplicate test was performed, and the results were expressed as CL counts per second. For further verification of the IS-promoted CL enhancement by superoxide, a separate experiment on cells treated for $48 \mathrm{~h}$ with IS was conducted with $50 \mu \mathrm{L}$ of recombinant bovine superoxide dismutase (SOD, $200 \mathrm{mU}$ ) 4 min after lucigenin injection. All chemicals in this assay were obtained from Sigma-Aldrich.

\subsection{Measurement of Cellular GSH and GSSG Levels}

Cellular GSH and GSSG contents were analyzed with a commercial kit (Oxis Research, Portland, OR, USA), and the GSH redox ratio was calculated using the following equation, as indicated by the manufacturer's instructions: redox ratio $(\%)=(\mathrm{GSH}-2 \mathrm{GSSG}) / \mathrm{GSSG}$ $\times 100$. The cell pellet was lysed by treatment with the GSH scavenger supplied in the kit. Cell lysate equivalent to $100 \mu \mathrm{g}$ of total proteins was added to the assay kit. Cellular GSH and GSSG contents were measured with an ELISA reader at $412 \mathrm{~nm}$ based on their individual standard curves.

\subsection{Statistics}

Continuous variables were shown as the mean \pm standard error of the mean (S.E.M). Unpaired $t$ test or one-way ANOVA was used to assess the differences between each group. The data were analyzed with the Prism 3.0 for Windows (GraphPad Software Inc, San Diego, CA, USA). A two-tailed $p$ value $<0.05$ was regarded as statistically significant.

\section{Results}

\section{1. $\mathrm{H}_{2} \mathrm{~S}$ Donors Attenuate IS-Induced Cell Damage}

We previously showed that IS is toxic for LLC-PK 1 cells [11]. In this study, we confirmed this and showed that co-treatment with the $\mathrm{H}_{2} \mathrm{~S}$ donor NaHS with IS significantly attenuates the release of the cell damage marker LDH (Figure 1A). The dose-dependent effect of $\mathrm{NaHS}$ on the reduction in LDH release caused by IS was found to be prominent at the time-points of 24 and $48 \mathrm{~h}$. However, NaHS alone did not affect LDH release. The results of the MTT assay showed that NaHS dose-dependently increased cell viability in the IS-treated cells (Figure 1B).

Using a slow-releasing $\mathrm{H}_{2} \mathrm{~S}$ donor, we found that GYY-4137 demonstrated tubuloprotection against IS with a more prominent effect on the reduction in LDH release, especially after $72 \mathrm{~h}$ of treatment (Figure 1C). GYY-4137 also showed a similar effect on the improvement of cell viability as that seen with NaHS treatment (Figure 1D).

\subsection{IS Inhibits Endogenous $\mathrm{H}_{2} \mathrm{~S}$ Production}

Since exogenous supplementation with $\mathrm{H}_{2} \mathrm{~S}$ protects tubular cells against IS, the indicated $\mathrm{H}_{2} \mathrm{~S}$ formation was impaired in the IS-treated cells. We therefore used an ion-selective electrode to monitor $\mathrm{H}_{2} \mathrm{~S}$ release from cells to confirm the tubule damaging effect of IS. The $\mathrm{H}_{2} \mathrm{~S}$ donor NaHS was given in a concentration range of 0.1 to $100 \mu \mathrm{M}$ and demonstrated a stable increase in recording voltage for $\sim 5 \mathrm{~min}$ (Figure $2 \mathrm{~A}$ ). The recording voltages correlated well with various concentrations of $\mathrm{NaHS}$ (insect in Figure 2A). Interestingly, IS significantly decreased $\mathrm{H}_{2} \mathrm{~S}$ release after $24-72 \mathrm{~h}$ of treatment when compared with the corresponding controls at the same time points (Figure 2B).

\subsection{Inhibition of $\mathrm{H}_{2} \mathrm{~S}$ Synthesis Aggravates IS-Induced Cell Damage}

We then examined the effects of $\mathrm{H}_{2} \mathrm{~S}$ inhibition on cell survival after IS treatment. AOAA, a non-selective $\mathrm{H}_{2} \mathrm{~S}$-producing enzyme blocker, markedly aggravated the ISinduced increase in $\mathrm{LDH}$ release and lowering of cell viability (Figure 3A,B). Treatment with AOAA alone showed no effect on cell viability but significantly attenuated $\mathrm{H}_{2} \mathrm{~S}$ release 
when compared with the untreated control group (Figure 3C). Moreover, AOAA decreased $\mathrm{H}_{2} \mathrm{~S}$ release more when compared with cells treated with IS only.

\subsection{IS Attenuates the Expression of $\mathrm{H}_{2} \mathrm{~S}$-Producing Enzymes}

Endogenous $\mathrm{H}_{2} \mathrm{~S}$ is produced by CBS, CSE, and 3-MST [17-19]. Reduced $\mathrm{H}_{2} \mathrm{~S}$ release in the IS-treated cells indicated a defect in $\mathrm{H}_{2} \mathrm{~S}$ production. We then tested whether IS affects protein expression in $\mathrm{H}_{2} \mathrm{~S}$-producing enzymes. Interestingly, IS significantly decreased CBS protein levels after 24 to $72 \mathrm{~h}$ of treatment when compared with the control group (Figure 4A). However, CSE expression only decreased at the time-point of $24 \mathrm{~h}$ after IS treatment and returned to levels similar to those in the controls thereafter (Figure 4B). 3-MST expression was decreased at all time-points after IS treatment and a prominent reduction was seen at $48 \mathrm{~h}$ (Figure $4 \mathrm{C}$ ).

Changes in the mRNA levels of these enzymes were similar to changes in their protein expression. IS significantly decreased CBS mRNA at all time-points (Figure 4D). CSE mRNA was decreased at 24 and $48 \mathrm{~h}$ and returned to a similar level as that in the control group after $72 \mathrm{~h}$ (Figure 4E). IS significantly reduced the 3-MST mRNA level at all timepoints (Figure 4F). Similar to protein expression, a prominent decrease in 3-MST mRNA was found at $48 \mathrm{~h}$.

\subsection{Blockade of AhR Reverses the Effect of IS on $\mathrm{H}_{2}$ S-Producing Enzyme Expression}

Co-treatment of a specific AhR blocker CH-223191 with IS in tubular cells for $72 \mathrm{~h}$ totally abrogated the effect of IS on the reduction in CBS protein expression (Figure 5A). CH223191 showed no effect on CSE protein expression in cells following $72 \mathrm{~h}$ of treatment with IS (Figure 5B). Both CBS and CSE were slightly upregulated in cells following treatment with $\mathrm{CH}-223191$ alone; however, these changes were insignificant. $\mathrm{CH}-223191$ also reversed the effect of IS on the reduction in 3-MST protein expression (Figure 5C).
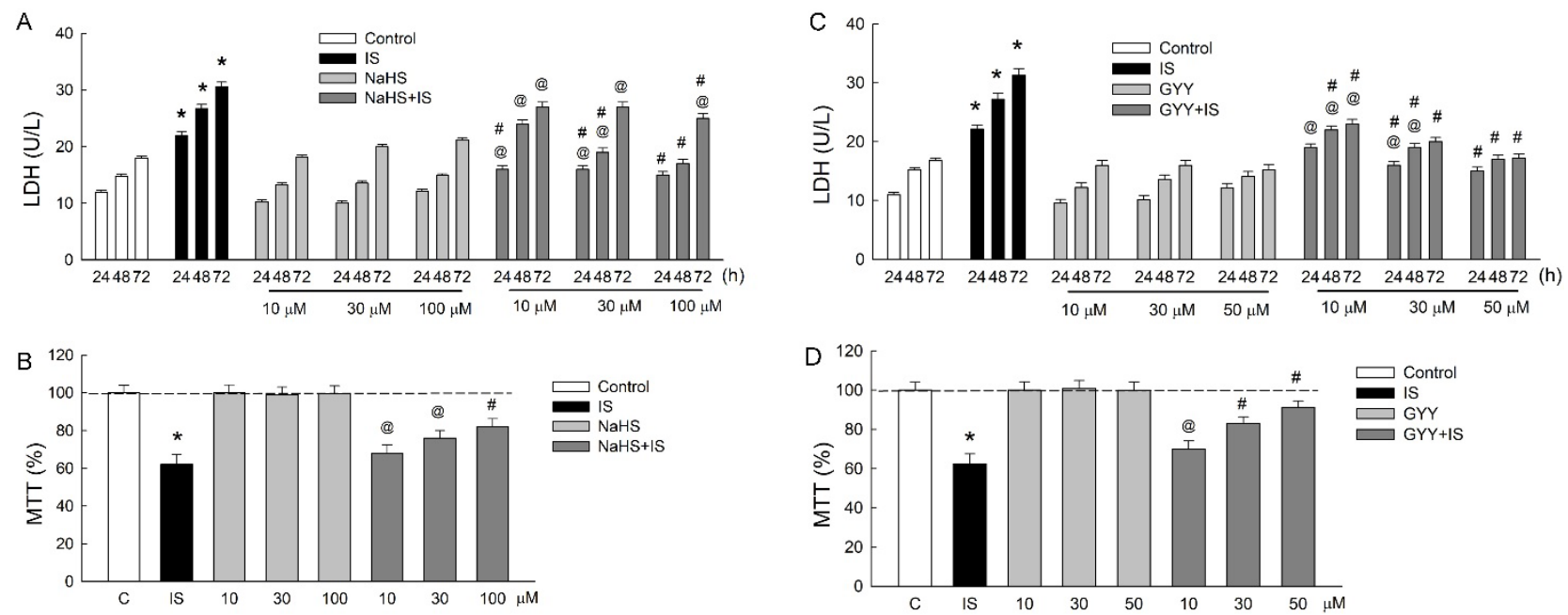

Figure 1. Supplementation with $\mathrm{H}_{2} \mathrm{~S}$ attenuates IS-induced tubular damage. The responses to IS and two $\mathrm{H}_{2} \mathrm{~S}$ donors NaHS and GYY-4137 (GYY) were evaluated in LLC-PK 1 cells. (A,C) The amount of $\mathrm{LDH}$ released was determined following treatment with IS or an $\mathrm{H}_{2} \mathrm{~S}$ donor, either alone or in combination for 24,48 , and $72 \mathrm{~h}$. (B,D) Cell viability was examined using the MTT assay after $72 \mathrm{~h}$ of treatment. $\mathrm{N}=6$ for each time-point and treatment. ${ }^{*} p<0.05$, IS vs. control group; @ $p<0.05, \mathrm{NaHS}$ + IS or GYY + IS vs. NaHS or GYY group, respectively; \# $p<0.05, \mathrm{NaHS+IS} \mathrm{or} \mathrm{GYY} \mathrm{+} \mathrm{IS} \mathrm{vs.} \mathrm{IS} \mathrm{group}$ at the same time-point. 

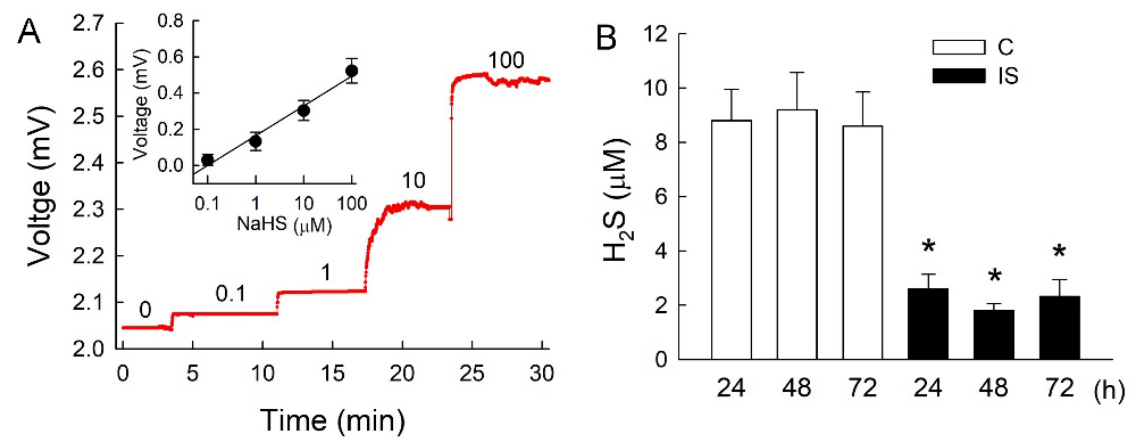

Figure 2. IS impairs $\mathrm{H}_{2} \mathrm{~S}$ release in LLC-PK 1 cells. (A) A representative tracing showed changes in the recording voltage $(\mathrm{mV})$ in response to a standard solution of $\mathrm{NaHS}$ ranging from 0.1 to $100 \mu \mathrm{M}$. The insect graph shows the standard curve of NaHS for six independent determinations. (B) Changes in $\mathrm{H}_{2} \mathrm{~S}$ levels in culture medium were measured after 24,48 , and $72 \mathrm{~h}$ of exposure to the vehicle solution (control, C) or IS treatment. $\mathrm{N}=6$ in each group and time-point. ${ }^{*} p<0.05$, IS vs. control (C) group at the same time-point.
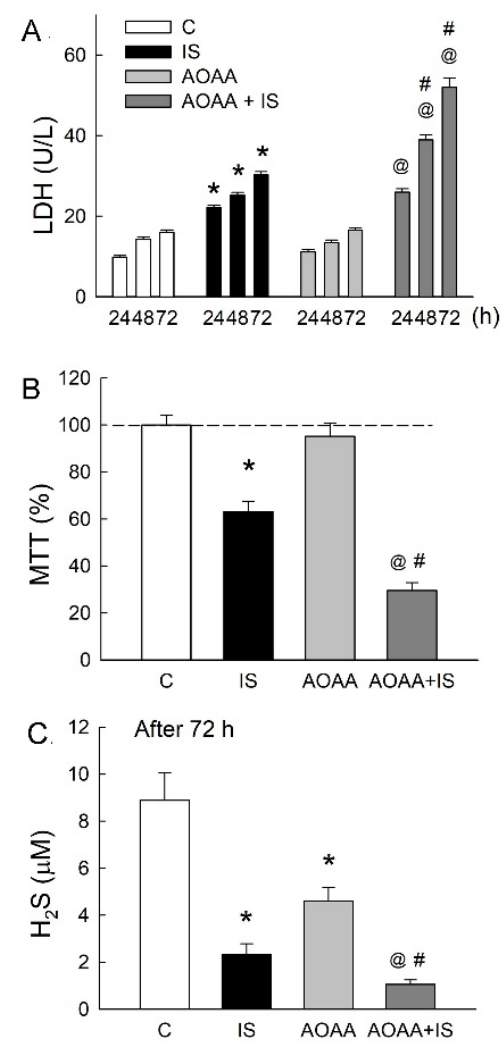

Figure 3. Inhibition of $\mathrm{H}_{2} \mathrm{~S}$-producing enzymes exacerbates IS-induced tubular damage. (A) Released LDH was measured under treatment with $10 \mathrm{mM}$ IS or $100 \mu \mathrm{M}$ AOAA alone or in combination for 24, 48, and $72 \mathrm{~h}$. C, control group treated with vehicle solution. (B) The cell viability was examined using the MTT assay after $72 \mathrm{~h}$ of treatment. (C) $\mathrm{H}_{2} \mathrm{~S}$ levels in the culture medium were measured after $72 \mathrm{~h}$ of treatment. Note that AOAA markedly attenuated cell survival and $\mathrm{H}_{2} \mathrm{~S}$ formation. $\mathrm{N}=6$ in each group or time-point. ${ }^{*} p<0.05$, IS vs. control (C) group; @ $p<0.05$, AOAA + IS vs. AOAA group; \# $p<0.05, \mathrm{AOAA}+$ IS vs. IS group. 
A
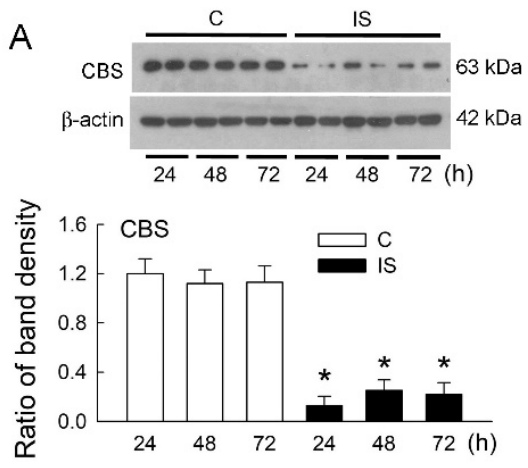

B
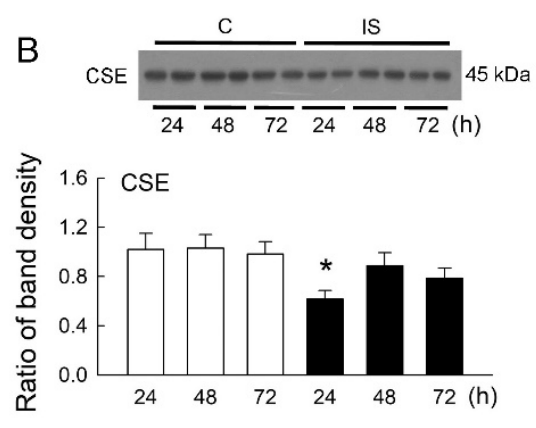

C
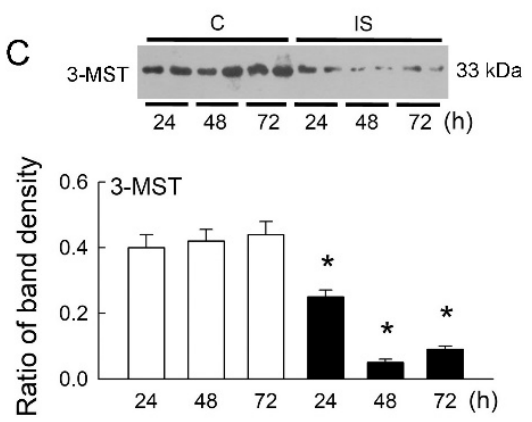
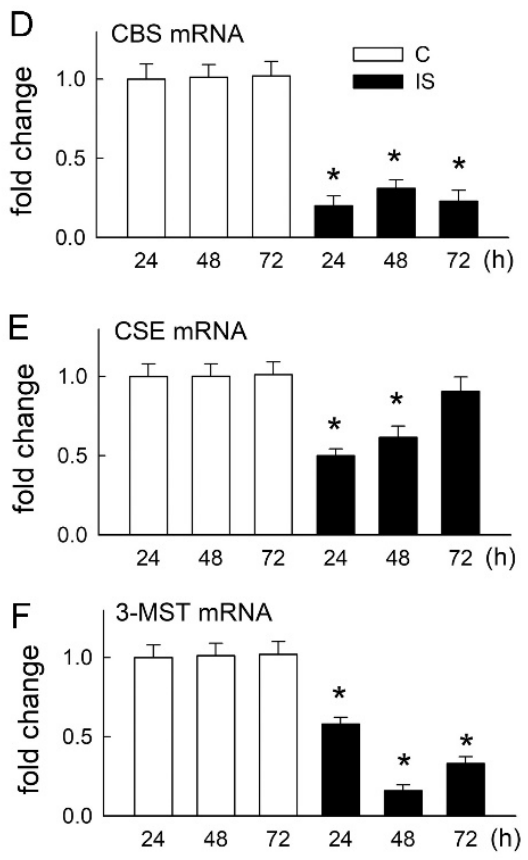

Figure 4. IS lowered the expression of $\mathrm{H}_{2} \mathrm{~S}$-producing enzymes. (A-C) The representative blots show two independent samples for the protein expression of CBS (A), CSE (B), and 3-MST (C) in cells after 24,48 , and $72 \mathrm{~h}$ of treatment with the vehicle solution (C, control) or IS. The lower bar graphs show the ratio of the band density of $\mathrm{H}_{2} \mathrm{~S}$-producing enzymes to $\beta$-actin. $\mathrm{N}=6$ in each group and time-point. (D-F) The mRNA expression of CBS (D), CSE (E), and 3-MST (F) in control cells and cells treated with IS was examined by RT-qPCR. N $=6$ in each group and time-point. ${ }^{*} p<0.05$, IS vs. control (C) group at the same time-point.

Changes in the mRNA level after AhR inhibition were similar to changes in protein expression (Figure 5D-F). CH-223191 abrogated the effect of IS on the reduction in both CBS and 3-MST mRNA levels and showed no effect on CSE mRNA.

\subsection{IS Decreases Sp1 Protein Activity}

The transcription factor $\mathrm{Sp} 1$ is known to regulate the expression of $\mathrm{H}_{2} \mathrm{~S}$-producing enzymes such as CBS and CSE [20]. This study further examined whether the effects of AhR blockade on IS-mediated downregulation of $\mathrm{H}_{2} \mathrm{~S}$-producing enzymes are dependent on Sp1. Our results show that IS does not affect Sp1 protein expression after various treatments (Figure 6A). IS, however, significantly attenuated the DNA binding activity of Sp1 (Figure 6B). Interestingly, AhR inhibition totally abolished the effect of IS on the attenuation of Sp1 activity. This clearly indicates that IS-mediated AhR activation affects transcription factor $\mathrm{Sp} 1$ binding activity. 

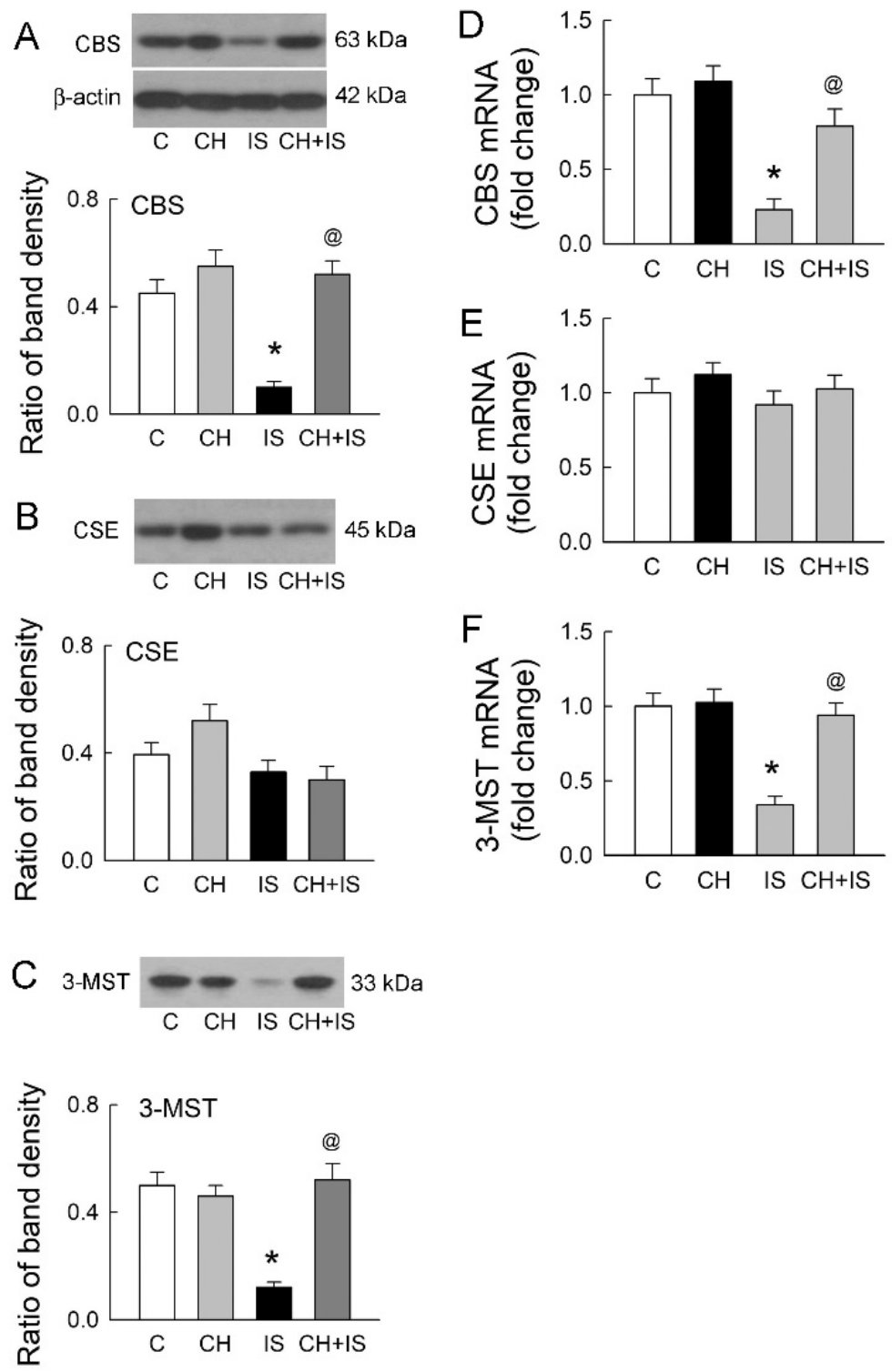

Figure 5. The inhibition of $A h R$ enhances the expression of $\mathrm{H}_{2} \mathrm{~S}$-producing enzymes. (A-C) The representative blots show one experiment on the protein expression of CBS (A), CSE (B), and 3-MST (C) in cells after $72 \mathrm{~h}$ of treatment with vehicle solution (C, control), a specific AhR blocker CH-223-191 $(\mathrm{CH})$, or IS alone or in combination. The lower bar graphs show the ratio of the band density of $\mathrm{H}_{2} \mathrm{~S}$-producing enzymes to $\beta$-actin. $\mathrm{N}=6$ in each group and time-point. (D-F) The mRNA expression of CBS (D), CSE (E), and 3-MST (F) in cells treated with PBS, CH, or IS alone or in combination was examined by RT-qPCR. $\mathrm{N}=6$ in each group and time-point. ${ }^{*} p<0.05$, IS vs. control (C) group; @ $p<0.05, \mathrm{CH}+$ IS vs. IS group.

\subsection{Supplementation with $\mathrm{H}_{2} \mathrm{~S}$ Increases the Cellular GSH Content}

$\mathrm{H}_{2} \mathrm{~S}$ itself not only functions as an antioxidant by scavenging ROS directly but also enhances the redox ability via glutathione (GSH) upregulation [21,22]. Our results show that the tubular cell content of GSH was lowered after $48 \mathrm{~h}$ of treatment with IS (Figure 7A). This effect could be reversed by co-treatment with the $\mathrm{H}_{2} \mathrm{~S}$ donor NaHS or GYY-4137 (GYY). Interestingly, the GSH cellular content increased after cells were treated with the $\mathrm{H}_{2} \mathrm{~S}$ donor only, and a significant increase in GYY-4137 was found. The inhibition of $\mathrm{H}_{2} \mathrm{~S}$-producing enzymes by AOAA, however, markedly attenuated the GSH content in IS-treated cells. IS also increased the cellular content of glutathione disulfide (GSSG) (Figure 7B). The $\mathrm{H}_{2} \mathrm{~S}$ donors NaHS and GYY-4137 lowered GSSG levels in the IS-treated 
cells, and a significant decrease was found after co-treatment with GYY-4137. A blockade of remnant $\mathrm{H}_{2} \mathrm{~S}$-producing enzyme activity by AOAA significantly increased the GSSG level in the IS-treated cells. We then calculated the GSH redox ratio to estimate the antioxidant status of cells, because this ratio is used as a marker of oxidative stress [23]. Exogenous supplementation with $\mathrm{H}_{2} \mathrm{~S}$ by $\mathrm{NaHS}$ or GYY-4137 increased this ratio. The highest ratio of $127 \%$ was observed in GYY-4137-treated cells, while the ratio was $105 \%$ in control cells (Figure 7C). IS significantly decreased the GSH redox ratio to less than half that of controls. Co-treatment of the $\mathrm{H}_{2} \mathrm{~S}$ donor NaHS or GYY-4137 with IS significantly increased this ratio. Inhibition of $\mathrm{H}_{2} \mathrm{~S}$-producing enzymes by AOAA in the IS-treated cells largely attenuated the GSH redox ratio to $12 \%$.

A
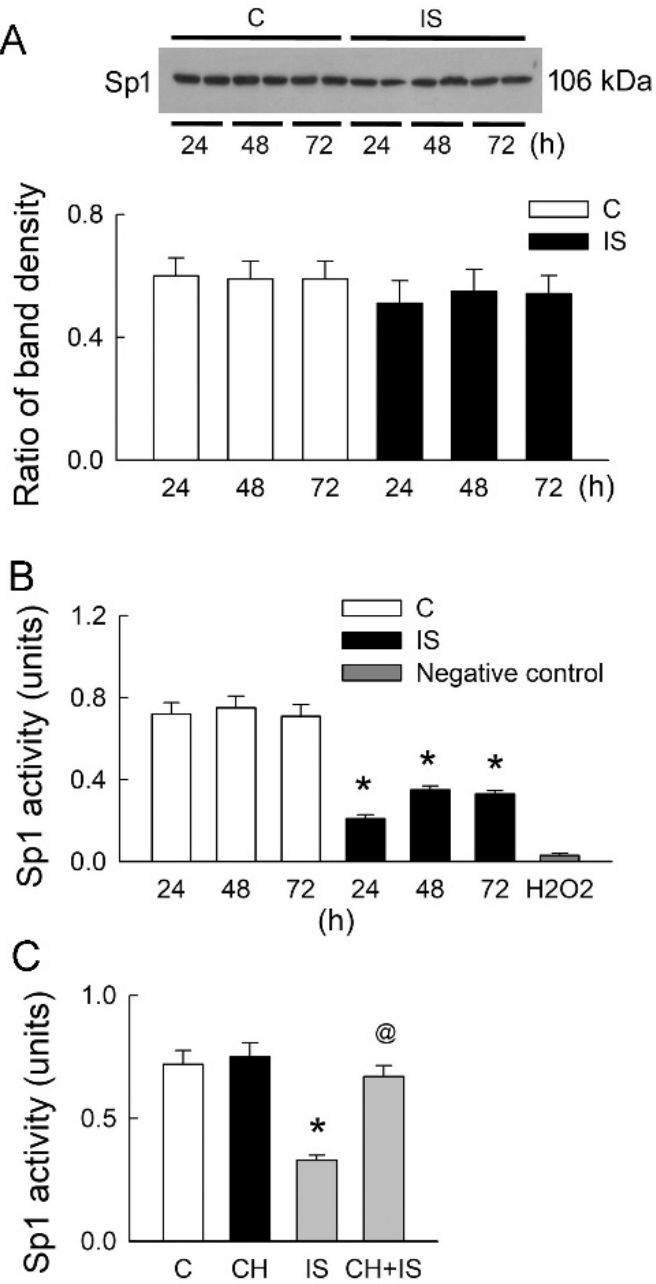

Figure 6. Changes in Sp1 protein expression and activity in LLC-PK 1 cells. (A) The representative blots show two experiments on Sp1 protein expression in cells after 24, 48, and $72 \mathrm{~h}$ of treatment with the vehicle solution (C, control) or IS. The lower bar graphs show the ratio of the band density of Sp1 to $\beta$-actin. $N=6$ in each group and time-point. (B) Sp1 protein activity was examined in control cells and cells treated with IS. A control group was treated with $400 \mu \mathrm{M} \mathrm{H}_{2} \mathrm{O}_{2}$ for $72 \mathrm{~h}$ to show the maximal decline in Sp1 activity. $\mathrm{N}=6$ in each group, treatment, and time-point. (C) The protein activity of Sp1 in cells treated with PBS (control), $\mathrm{CH}$, or IS alone or in combination was examined. $\mathrm{N}=6$ in each group. ${ }^{*} p<0.05$, IS vs. control (C) group (at the same time-point); @ $p<0.05, \mathrm{CH}+\mathrm{IS}$ vs. IS group.

\subsection{Supplementation with $\mathrm{H}_{2} \mathrm{~S}$ Donors Attenuates Superoxide Formation Caused by IS}

As $\mathrm{H}_{2} \mathrm{~S}$ increased the GSH content, we examined whether this effect is associated with oxygen radical formation. Before administration of the probe for detecting superoxide release, lucigenin displayed a basal CL level of around 500 counts (the typical recording 
tracings in Figure 8A). In cells treated with IS for $48 \mathrm{~h}$, an abrupt increase in lucigeninenhanced CL, representing superoxide formation, was observed in the culture medium, and this increased gradually during recording. Co-treatment of the $\mathrm{H}_{2} \mathrm{~S}$ donor GYY-4137 (GYY) with IS significantly lowered lucigenin-enhanced CL recording. The inhibition of $\mathrm{H}_{2} \mathrm{~S}$-producing enzymes by AOAA markedly enhanced lucigenin-induced CL in IS-treated cells. Recombinant SOD specifically suppressed the CL count after 4 min of lucigenin injection; this confirmed that the increased CL count was associated with superoxide production caused by IS. The results for the area under the curve (AUC) showed that IS increases lucigenin-dependent $\mathrm{CL}$ after $72 \mathrm{~h}$ of treatment when compared with control cells. Treatment with GYY-4137 or AOAA alone showed no effect on the CL count; however, the CL count significantly decreased and increased, respectively, after co-treatment with IS (Figure 8B).
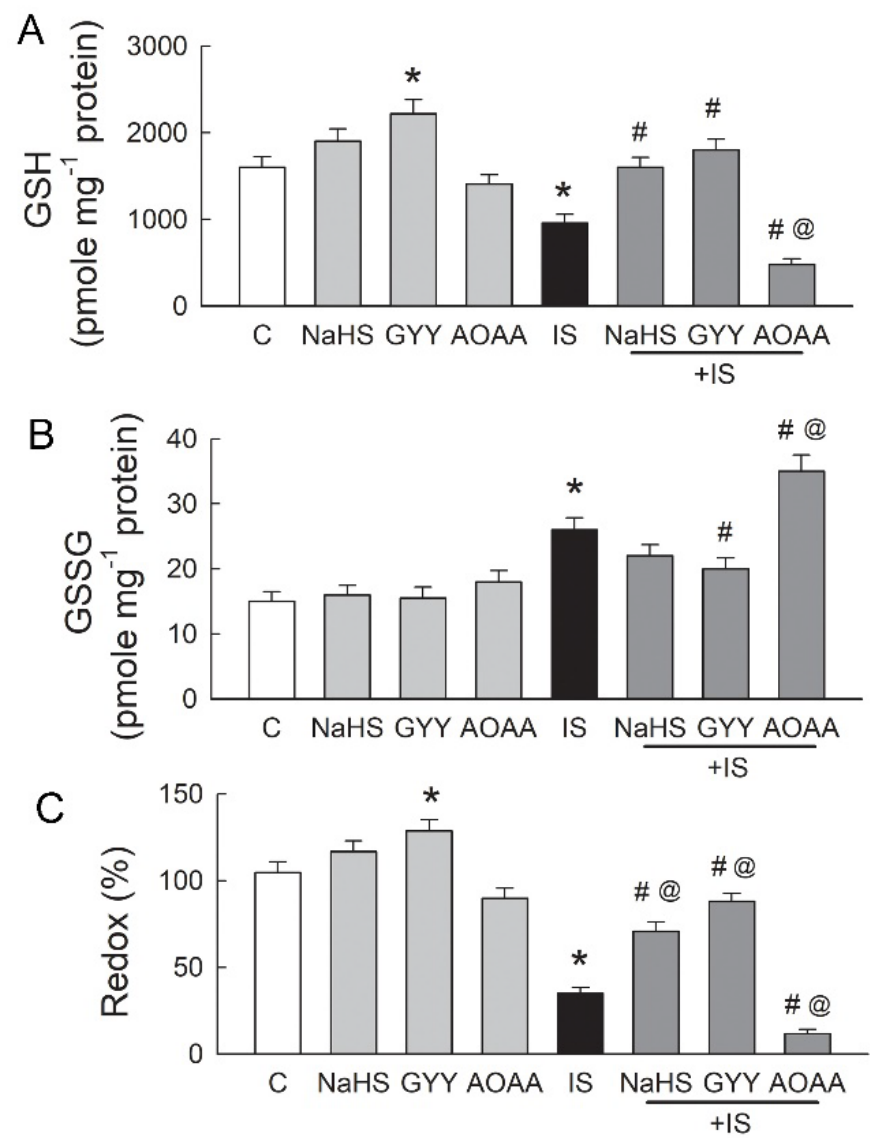

Figure 7. Supplementation with $\mathrm{H}_{2} \mathrm{~S}$ reverses the poor redox status caused by IS. (A) Cellular glutathione (GSH) content in cells after $48 \mathrm{~h}$ of treatment with the vehicle solution (C, control), $\mathrm{H}_{2} \mathrm{~S}$ donor NaHS $(100 \mu \mathrm{M}), \mathrm{GYY}-4137(\mathrm{GYY}, 50 \mu \mathrm{M}), \mathrm{H}_{2} \mathrm{~S}$ inhibitor AOAA $(100 \mu \mathrm{M})$, or IS in alone or in combination. (B) Cellular glutathione disulfide (GSSG) content in cells following the same treatments mentioned above. (C) The GSH redox ratio represents the index of antioxidant defense in cells after various treatments. $\mathrm{N}=6$ in each group. ${ }^{*} p<0.05$, drug vs. control (C) group; @ $p<0.05$, drug + IS vs. IS group; $\# p<0.05$, drug + IS vs. drug only group. 

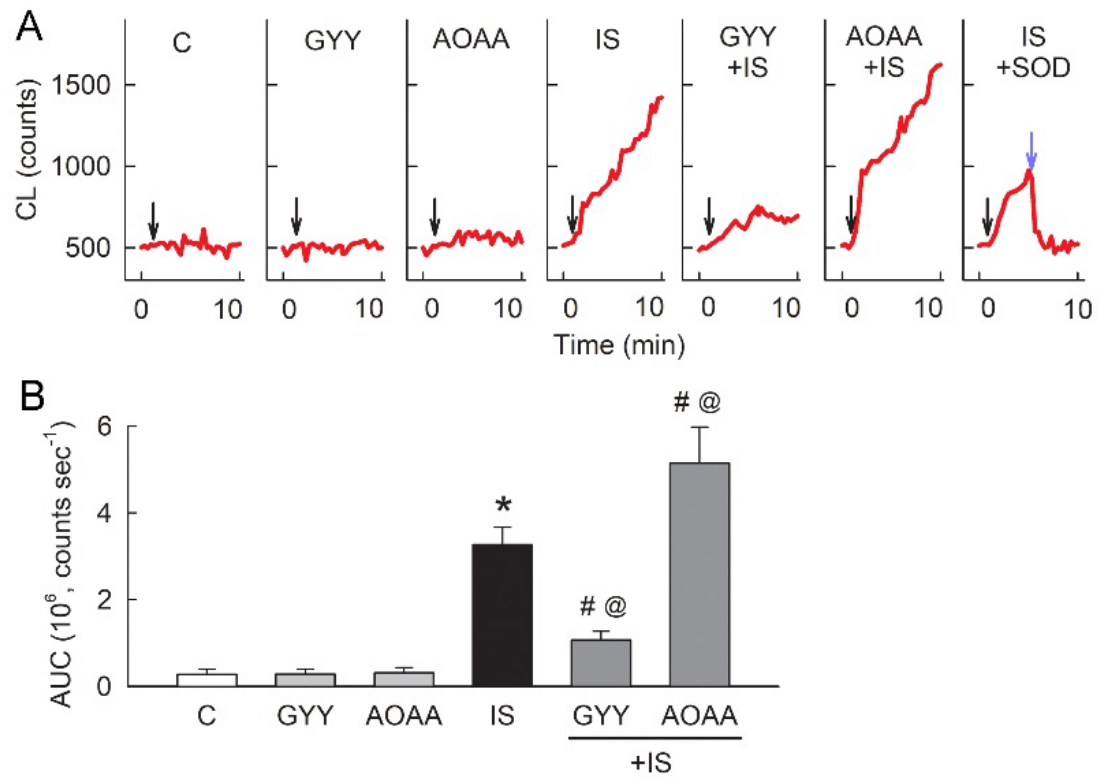

Figure 8. Supplementation with $\mathrm{H}_{2} \mathrm{~S}$ reduces IS-induced superoxide formation. (A) The representative tracings show changes in chemiluminescence (CL) in the culture medium after $48 \mathrm{~h}$ of treatment with the vehicle solution (control, C), 10 mM IS, $50 \mu \mathrm{M}$ GYY-4173 (GYY), or $100 \mu \mathrm{M}$ AOAA alone, or in combination. The black arrows indicate lucigenin injection after $1 \mathrm{~min}$ of baseline recording. In the rightmost tracing, SOD treatment (200 $\mathrm{mU}$ as indicated by a light blue arrow) decreased CL in cells treated with IS for $48 \mathrm{~h}$, which confirms that the CL recordings of lucigenin are derived from superoxide. (B) The bar graph shows the total amount of CL as the area under the curve (AUC). $\mathrm{N}=6$ in each group. Note that IS-induced superoxide formation was attenuated by the $\mathrm{H}_{2} \mathrm{~S}$ donor GYY-4173 and enhanced by the inhibition of endogenous $\mathrm{H}_{2} \mathrm{~S}$ production via AOAA. ${ }^{*} p<0.05$, IS vs. control (C) group; @ $p<0.05$, drug + IS vs. IS group; \# $p<0.05$, drug + IS vs. drug only group.

\section{Discussion}

As illustrated in Figure 9, IS directly damages renal tubular cells through an increase in oxidative stress. In the proximal renal tubular cells, IS significantly reduces endogenous $\mathrm{H}_{2} \mathrm{~S}$ production. Exogenously given $\mathrm{H}_{2} \mathrm{~S}$ donors ameliorate IS-induced tubular damage, whereas the impediment of $\mathrm{H}_{2} \mathrm{~S}$ generation through the inhibition of $\mathrm{H}_{2} \mathrm{~S}$-producing enzymes exacerbates this damage. These results indicate that defective $\mathrm{H}_{2} \mathrm{~S}$ production is implicated in the pathogenesis of IS-induced tubular injury. To elucidate how $\mathrm{H}_{2} \mathrm{~S}$ is impaired by IS, we found that IS downregulates the $\mathrm{H}_{2} \mathrm{~S}$-producing enzymes CBS, CSE, and 3-MST, which is part of the mechanism for decreasing $\mathrm{H}_{2} \mathrm{~S}$ production in proximal tubular cells. Interestingly, IS also impairs the DNA binding activity of the upstream transcription factor Sp1, which is known to be responsible for the regulation of $\mathrm{H}_{2} \mathrm{~S}$-producing enzyme expression. The deleterious effect of IS on $\mathrm{H}_{2} \mathrm{~S}$-producing enzymes and upstream Sp1 activity can be abrogated by the AhR blocker, which supports the role of AhR in IS-mediated defective $\mathrm{H}_{2} \mathrm{~S}$ production and related tubular damage. Furthermore, a lack of $\mathrm{H}_{2} \mathrm{~S}$ in IS-treated tubular cells depletes the GSH cell content, as well as increasing superoxide formation, leading to oxidative stress. Exogenous supplementation with $\mathrm{H}_{2} \mathrm{~S}$ and endogenous blockade of $\mathrm{H}_{2} \mathrm{~S}$ formation to IS-treated cells alleviated and exacerbated oxidative stress, respectively, by superoxide formation. 


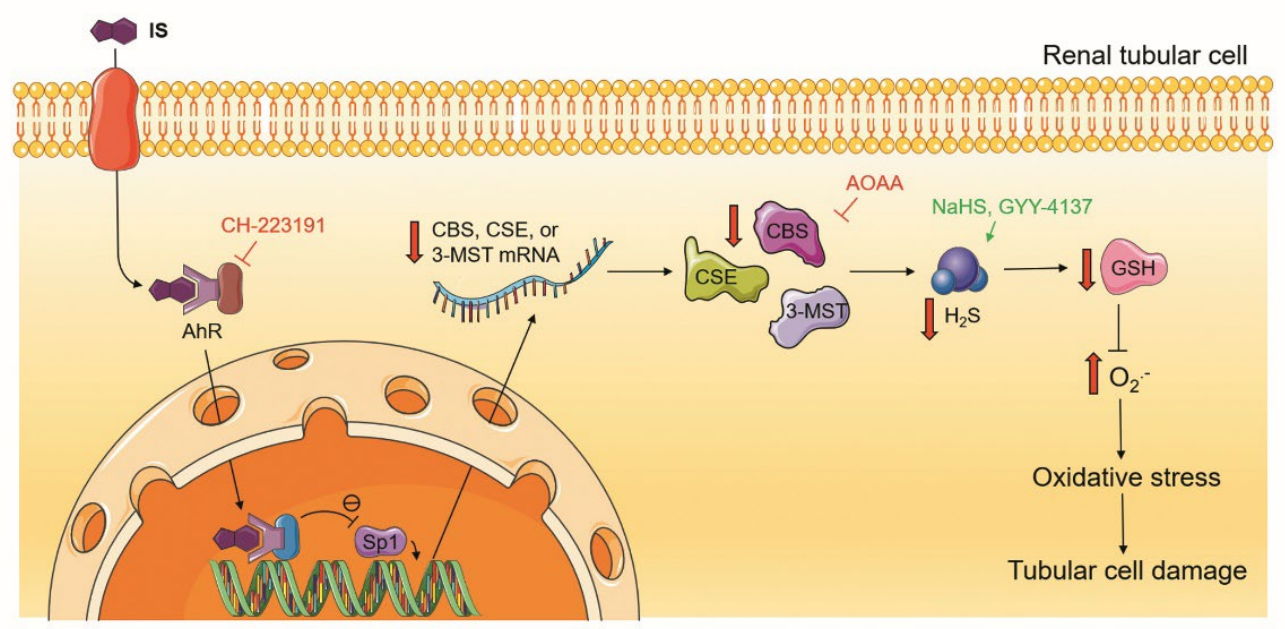

Figure 9. Schematic diagram showing how IS induced renal tubular cell damage. IS was taken up by tubular cells via OATs, as previously reported [11]. IS then decreased the protein activity of transcription factor Sp1. This effect was abolished after the inhibition of AhR via a specific blocker $\mathrm{CH}-223191$, indicating that AhR decreases the DNA binding activity of Sp1. The lowered Sp1 activity probably impaired the protein expression of the $\mathrm{H}_{2} \mathrm{~S}$-producing enzymes CBS, CSE, and 3-MST as well as $\mathrm{H}_{2} \mathrm{~S}$ formation. Exogenous $\mathrm{H}_{2} \mathrm{~S}$ supplementation through the $\mathrm{H}_{2} \mathrm{~S}$ donors NaHS or GYY-4137 ameliorated IS-induced tubular damage by increasing the cellular GSH level and lowering superoxide $\left(\mathrm{O}_{2}{ }^{\bullet-}\right)$ release. Inhibition of $\mathrm{H}_{2}$ S-producing enzymes by AOAA exacerbated tubular injury caused by IS via the enhancement of oxidative stress. Parts of the figure were drawn using pictures from Servier Medical Art. Servier Medical Art by Servier is licensed under a Creative Commons Attribution 3.0 Unported License (https://creativecommons.org/licenses/by/3.0/ (accessed on 1 August 2021)).

IS, a protein-bound uremic toxin that is normally eliminated by healthy kidneys, accumulates during renal function deterioration. We previously reported that organic anion transporters (OATs) help the transcellular transport of IS across the cell membranes of the proximal renal tubules [24]. Although this study did not test the effect of OATs on IS uptake, previous studies have provided in vivo evidence that IS and other uremic toxins accumulate in the plasma of OAT knockout mice [25]. Moreover, IS exerts its nephrotoxicity by directly promoting tubular cell death after cell uptake, as we previously reported [26]. Consistent with this, our results show that IS has a direct tubulotoxic effect on LLC-PK 1 . This, however, can be attenuated through the inhibition of AhR. A previous study demonstrated that IS is a strong agonist to human AhR [27]. In the absence of IS, AhR resides in the cytosol as a complex with a dimer of the chaperone heat shock protein 90 (HSP90) [28]. Upon binding to cytoplasmic AhR, the complex of IS/AhR subsequently translocates into the nucleus and dissociates from HSP90 to form a heterodimer with aryl hydrocarbon receptor nuclear translocator (ARNT) as a transcriptional activator. The IS/AhR/ARNT complex binds with the xenobiotic-response element (XRE) sequence in the promoter region of ROS-producing enzyme genes, such as cytochrome P450 enzymes (CYPs), which renders the tubular cells vulnerable to oxidative stress damage. Hence, IS has direct oxidative cytotoxic effects on the renal tubular cells and contributes to the development of tubulointerstitial injury, leading to renal fibrosis, a final stage of CKD [26]. This study consistently showed IS-induced oxidative stress in tubular cells. However, the oxidative stress seen in IS-treated tubular cells was dependent on a weakening of the effect of antioxidant $\mathrm{H}_{2} \mathrm{~S}$.

In hepatic cells, AhR and Sp1 coordinately bind to the XRE and GC box sequence in the proximal promoter region to determine the constitutive expression of CYP1A1, which is responsible for the phase I metabolism of endogenous xenobiotics compounds, such as IS. Notably, AhR bound to the XRE/GC box site can further recruit Sp1 to promote CYP1A1 expression [29]. Our results also demonstrated that there is a protein interaction 
between AhR and Sp1. Unlike the synergistic effect of AhR and Sp1 in the regulation of CYP1A1 expression, here, we showed that AhR negatively regulates Sp1 activity, as the inhibition of AhR increases Sp1 activity (Figure 6). Sp1 is a zinc finger transcription factor that binds to GC box regions in thousands of genes involved in many cellular processes, including cell differentiation, proliferation, and cell growth [30]. A previous study reported that post-translational modifications of Sp1 activity, including phosphorylation, glycosylation, acetylation, sumoylation, and ubiquitylation, influence its DNA binding affinity and thereby regulate its transcriptional activity, modulating target gene expression [31]. In rat kidneys suffering from ischemia/reperfusion insult, extracellular-signal-regulated kinase 1/2 (ERK)-mediated phosphorylation of Sp1 was shown to be responsible for decreased transcriptional activity of Sp1, leading to a reduction in CBS gene expression [20]. Interestingly, a study reported that $\mathrm{AhR}$ also functions in pathways outside its role in detoxification by cross-talk with multiple signal transduction pathways, including those involved in the activation of ERK [32]. Moreover, AhR-mediated oxidative stress also affects $\mathrm{Sp} 1$ activity. A previous study showed that hydrogen peroxide $\left(\mathrm{H}_{2} \mathrm{O}_{2}\right)$ treatment increased the methylation of Sp1 and repressed Sp1 transcriptional activity [33]. Further study is required to identify the roles of ERK and $\mathrm{H}_{2} \mathrm{O}_{2}$ on Sp1 function in terms of the regulation of $\mathrm{H}_{2} \mathrm{~S}$-producing enzyme expression after IS treatment.

In human embryonic kidney cells, the CSE gene promoter displayed a high binding affinity for Sp1 [34]. In human smooth muscle cells of the aorta, there are Sp1 consensus binding sites present in the core promoter of the human CSE gene, and $\mathrm{H}_{2} \mathrm{~S}$ production by CSE is essential for the maintenance of the smooth muscle cell phenotype [35]. Moreover, transactivating roles for Sp1 and nuclear factor Y play an essential role in regulating CBS activity. The alteration of Sp1 phosphorylation or Sp1 synergism with nuclear factor $Y$ influences the differential binding of Sp1 to the CBS promoter and then affects CBS gene expression [36]. Therefore, $\mathrm{Sp} 1$ is a regulatory factor that modulates $\mathrm{H}_{2} \mathrm{~S}$-producing enzyme expression and $\mathrm{H}_{2} \mathrm{~S}$ production to make a cell-specific pattern of $\mathrm{H}_{2} \mathrm{~S}$ renoprotection. In addition to the transcriptional effect of Sp1, CSE activity for $\mathrm{H}_{2} \mathrm{~S}$ production has been reported to be affected by changes in intracellular $\mathrm{Ca}^{2+}\left(\left[\mathrm{Ca}^{2+}\right] \mathrm{i}\right)$ directly, where an increase in $\left[\mathrm{Ca}^{2+}\right] \mathrm{i}$ enhances CSE activity and vice versa [37]. We previously showed that IS-mediated AhR activation can induce a possible $\left[\mathrm{Ca}^{2+}\right]$ i overload via hyperfunction of the $\mathrm{Ca}^{2+}$-permeable TRPV1 in tubular cells [38]. [ $\left.\mathrm{Ca}^{2+}\right]$ i overload-mediated by TRPV1 to reduce CSE activity needs further study. Similar to CSE, an increase in $\left[\mathrm{Ca}^{2+}\right] \mathrm{i}$ also attenuates the activity of the 3-MST/CAT pathway for $\mathrm{H}_{2} \mathrm{~S}$ production, and the enzyme regulated by $\mathrm{Ca}^{2+}$ has been suggested to be CAT and not 3-MST [39]. Furthermore, oxidative stress significantly suppresses 3-MST activity via the enhanced oxidation of three redox-sensitive cysteines (Cys154, Cys247, Cys263) in the catalytic site of 3-MST, reducing $\mathrm{H}_{2} \mathrm{~S}$ production [40]. As the present results show that oxidative stress is associated with IS/AhR-mediated tubular damage by impeding $\mathrm{H}_{2} \mathrm{~S}$ formation, a detailed study is required to see whether this is dependent on the increased oxidation of 3-MST.

Alteration of $\mathrm{H}_{2} \mathrm{~S}$ has been implicated in various kidney diseases, including renal ischemia/reperfusion injury (IRI) [41], hypertensive kidney injury [42,43], diabetic nephropathy [4,44], obstructive kidney injury [45], and CKD progression [6,8]. IRI is the most well-studied model to demonstrate the impact of altered $\mathrm{H}_{2} \mathrm{~S}$ production on the renal tubules. In the IRI model of the rat kidneys, both CSE and CBS protein levels are decreased at 4 days after ischemia, and this persists throughout this period for up to 21 days. Impaired $\mathrm{H}_{2} \mathrm{~S}$ production significantly increases formation of the phosphorylated form of histone $\mathrm{H} 2 \mathrm{~A}(\mathrm{p} \gamma \mathrm{H} 2 \mathrm{AX})$, which indicates that oxidative damage to DNA occurs in renal tubular cells in response to IRI. Instead, exogenous supplementation CSE-deficient mice with $\mathrm{H}_{2} \mathrm{~S}$ attenuates the area of renal cortical necrosis, reduces the quantity of $\mathrm{p} \gamma \mathrm{H} 2 \mathrm{AX}$-positive cells, retards the renal function decline, and rescues animal survival [46]. In this study, we consistently showed that the deleterious effect of IS on tubular cell damage can be significantly reversed by the $\mathrm{H}_{2} \mathrm{~S}$ donors NaHS or GYY-4137. $\mathrm{H}_{2} \mathrm{~S}$ deficiency, therefore, increases the vulnerability of the renal tubules to oxidative damage. 
Previous studies showed that the mechanisms underlying IS-induced tubular oxidative damage include increases in NOX4 activity and ROS generation [47], downregulation of Nrf2 through NF- $\mathrm{BB}$ activation, a subsequent reduction in the expression of the antioxidant HO-1 [48], and decreases in the activity of GSH and SOD, which are responsible for defense against oxidative stress in the renal tubules $[49,50]$. However, there is no available literature that discusses the role of $\mathrm{H}_{2} \mathrm{~S}$ in IS-mediated tubular damage. In fact, $\mathrm{H}_{2} \mathrm{~S}$ and its dissociated ion $\mathrm{HS}^{-}$act as a powerful one-electron chemical reluctant and have a high capacity to scavenge ROS by directly reacting to superoxide and $\mathrm{H}_{2} \mathrm{O}_{2}$ [51,52]. In this study, we consistently showed that exogenous supplementation with $\mathrm{H}_{2} \mathrm{~S}$ attenuates superoxide formation in the IS-treated tubular cells. In addition to $\mathrm{H}_{2} \mathrm{~S}$ itself, a previous study demonstrated that $\mathrm{H}_{2} \mathrm{~S}$ increases the intracellular GSH level by enhancing the production of the cystine/cysteine transporter and redistributes GSH to the mitochondria, where a large amount of ROS is produced [22]. In this study, we also showed that exogenous supplementation with $\mathrm{H}_{2} \mathrm{~S}$ increases the intracellular GSH content in IS-treated tubular cells. Hence, $\mathrm{H}_{2} \mathrm{~S}$, together with GSH recruitment, act as an overall antioxidant defense against oxidative damage triggered by IS/AhR signaling. Accordingly, impaired $\mathrm{H}_{2} \mathrm{~S}$ production by IS renders tubular cells vulnerable to oxidative stress damage and underlies one of the mechanisms of IS-mediated tubulotoxicity, which inevitably leads to tubulointerstitial inflammation and renal fibrosis.

The single cell line used is the limitation of our study. LLC-PK 1 is the most widely used model to study the harmful uremic toxins on renal tubular cells [11,49,53,54]. Certainly, additional proximal renal tubular cell lines or in vivo rat CKD model should be considered to provide consistency proofs to explore the deleterious effect of IS on renal tubular damage.

\section{Conclusions}

Our results show that treatment of the proximal tubule cells with IS impairs $\mathrm{H}_{2} \mathrm{~S}$ formation and induces tubular oxidative damage. Downregulation of the $\mathrm{H}_{2} \mathrm{~S}$-producing enzymes CBS, CSE, or 3-MST and a decrease in Sp1 DNA binding activity underlie the mechanism behind the decrease in $\mathrm{H}_{2} \mathrm{~S}$ production in the proximal renal tubules. As expected, AhR is involved in IS-mediated defective $\mathrm{H}_{2} \mathrm{~S}$ production and subsequent renal tubular damage. The accumulation of IS during CKD progression impairs $\mathrm{H}_{2} \mathrm{~S}$ formation, rendering tubular cells more susceptible to oxidative injury. Thus, $\mathrm{H}_{2} \mathrm{~S}$ may serve as a potential therapeutic molecule to alleviate renal function decline in CKD.

Author Contributions: Study design: C.-L.L., M.-C.M.; Literature survey: C.-L.L., C.-H.L., W.-B.W., C.-M.Z., K.-C.L., M.-C.M.; Data analysis: C.-L.L., W.-B.W., C.-M.Z., M.-C.M.; Article drafting: C.-L.L., C.-H.L., M.-C.M. All authors have read and agreed to the published version of the manuscript.

Funding: The current study was supported by grants from the Cardinal Tien Hospital (108-CTH-FJU02), the Ministry of Science and Technology, Taiwan (MOST 108-2314-B-030-004-MY3, 110-2314-B-030005-MY3) and Fu Jen Catholic University Hospital PL-201808003-V.

Institutional Review Board Statement: Not applicable.

Informed Consent Statement: Not applicable.

Data Availability Statement: Data are contained within the article.

Conflicts of Interest: The authors declare no conflict of interest.

$\begin{array}{ll}\text { Abbreviations } \\ \text { 3-MST } & \text { 3-mercaptopyruvate sulfurtransferase } \\ \text { AhR } & \text { Aryl hydrocarbon receptor } \\ \text { AOAA } & \text { Aminooxyacetic acid } \\ \text { ARNT } & \text { Aryl hydrocarbon receptor nuclear translocator } \\ \text { CAT } & \text { Cystathionine aminotransferase } \\ \text { CBS } & \text { Cystathionine } \beta \text {-synthase }\end{array}$




$\begin{array}{ll}\text { CKD } & \text { Chronic kidney disease } \\ \text { CSE } & \text { Cystathionine } \gamma \text {-lyase } \\ \text { CYPs } & \text { Cytochrome P450 enzymes } \\ \text { ERK } & \text { Extracellular-signal-regulated kinase } \\ \text { ESRD } & \text { End-stage renal disease } \\ \text { GAPDH } & \text { Glyceraldehyde-3-phosphate dehydrogenase } \\ \text { GSH } & \text { Reduced glutathione } \\ \text { GSSG } & \text { Glutathione disulfide } \\ \mathrm{H}_{2} \mathrm{~S} & \text { Hydrogen sulfide } \\ \text { HSP90 } & \text { Heat shock protein } 90 \\ \text { IRI } & \text { Ischemia/reperfusion injury } \\ \text { IS } & \text { Indoxyl sulfate } \\ \text { NF- } \kappa \text { B } & \text { Nuclear factor- }- \text { B } \\ \text { Nrf2 } & \text { Nuclear factor erythroid 2-related factor 2 } \\ \text { OATs } & \text { Organic anion transporters } \\ \text { ROS } & \text { Reactive oxygen species } \\ \text { SOD } & \text { Superoxide dismutase } \\ \text { Sp1 } & \text { Specificity protein 1 } \\ \text { TGF- } \beta 1 & \text { Transforming growth factor- } \beta 1 \\ \text { TRPV1 } & \text { Transient receptor potential vanilloid 1 } \\ \text { XRE } & \text { Xenobiotic-response element }\end{array}$

\section{References}

1. Toombs, C.F.; Insko, M.A.; Wintner, E.A.; Deckwerth, T.L.; Usansky, H.; Jamil, K.; Goldstein, B.; Cooreman, M.; Szabo, C. Detection of exhaled hydrogen sulphide gas in healthy human volunteers during intravenous administration of sodium sulphide. Br. $J$. Clin. Pharmacol. 2010, 69, 626-636. [CrossRef] [PubMed]

2. Klingerman, C.M.; Trushin, N.; Prokopczyk, B.; Haouzi, P. $\mathrm{H}_{2} \mathrm{~S}$ concentrations in the arterial blood during $\mathrm{H}_{2} \mathrm{~S}$ administration in relation to its toxicity and effects on breathing. Am. J. Physiol. Regul. Integr. Comp. Physiol. 2013, 305, R630-R638. [CrossRef] [PubMed]

3. Mathai, J.C.; Missner, A.; Kügler, P.; Saparov, S.M.; Zeidel, M.L.; Lee, J.K.; Pohl, P. No facilitator required for membrane transport of hydrogen sulfide. Proc. Natl. Acad. Sci. USA 2009, 106, 16633-16638. [CrossRef]

4. Yamamoto, J.; Sato, W.; Kosugi, T.; Yamamoto, T.; Kimura, T.; Taniguchi, S.; Kojima, H.; Maruyama, S.; Imai, E.; Matsuo, S.; et al. Distribution of hydrogen sulfide $\left(\mathrm{H}_{2} \mathrm{~S}\right)$-producing enzymes and the roles of the $\mathrm{H}_{2} \mathrm{~S}$ donor sodium hydrosulfide in diabetic nephropathy. Clin. Exp. Nephrol. 2013, 17, 32-40. [CrossRef] [PubMed]

5. Tomita, M.; Nagahara, N.; Ito, T. Expression of 3-Mercaptopyruvate Sulfurtransferase in the Mouse. Molecules 2016, 21, 1707. [CrossRef] [PubMed]

6. Perna, A.F.; Ingrosso, D. Low hydrogen sulphide and chronic kidney disease: A dangerous liaison. Nephrol. Dial. Transplant. 2012, 27, 486-493. [CrossRef] [PubMed]

7. Luo, R.; Hu, S.; Liu, Q.; Han, M.; Wang, F.; Qiu, M.; Li, S.; Li, X.; Yang, T.; Fu, X.; et al. Hydrogen sulfide upregulates renal AQP-2 protein expression and promotes urine concentration. FASEB J. 2019, 33, 469-483. [CrossRef] [PubMed]

8. Aminzadeh, M.A.; Vaziri, N.D. Downregulation of the renal and hepatic hydrogen sulfide $\left(\mathrm{H}_{2} \mathrm{~S}\right)$-producing enzymes and capacity in chronic kidney disease. Nephrol. Dial. Transplant. 2011, 27, 498-504. [CrossRef] [PubMed]

9. Wu, D.; Luo, N.; Wang, L.; Zhao, Z.; Bu, H.; Xu, G.; Yan, Y.; Che, X.; Jiao, Z.; Zhao, T.; et al. Hydrogen sulfide ameliorates chronic renal failure in rats by inhibiting apoptosis and inflammation through ROS/MAPK and NF-кB signaling pathways. Sci. Rep. 2017, 7, 455. [CrossRef] [PubMed]

10. Perna, A.F.; Luciano, M.G.; Ingrosso, D.; Pulzella, P.; Sepe, I.; Lanza, D.; Violetti, E.; Capasso, R.; Lombardi, C.; De Santo, N.G. Hydrogen sulphide-generating pathways in haemodialysis patients: A study on relevant metabolites and transcriptional regulation of genes encoding for key enzymes. Nephrol. Dial. Transplant. 2009, 24, 3756-3763. [CrossRef] [PubMed]

11. Lu, C.L.; Liao, C.H.; Lu, K.C.; Ma, M.C. TRPV1 Hyperfunction Involved in Uremic Toxin Indoxyl Sulfate-Mediated Renal Tubular Damage. Int. J. Mol. Sci. 2020, 21, 6212. [CrossRef] [PubMed]

12. Tumur, Z.; Shimizu, H.; Enomoto, A.; Miyazaki, H.; Niwa, T. Indoxyl sulfate upregulates expression of ICAM-1 and MCP-1 by oxidative stress-induced NF-kappaB activation. Am. J. Nephrol. 2010, 31, 435-441. [CrossRef] [PubMed]

13. Rapa, S.F.; Di Iorio, B.R.; Campiglia, P.; Heidland, A.; Marzocco, S. Inflammation and Oxidative Stress in Chronic Kidney Disease-Potential Therapeutic Role of Minerals, Vitamins and Plant-Derived Metabolites. Int. J. Mol. Sci 2019, 21, 263. [CrossRef] [PubMed]

14. Barile, F.A. Principles of Toxicology Testing; CRC Press: Boca Raton, FL, USA, 2007; p. 189. [CrossRef]

15. Yang, G.; Wu, L.; Jiang, B.; Yang, W.; Qi, J.; Cao, K.; Meng, Q.; Mustafa, A.K.; Mu, W.; Zhang, S.; et al. $\mathrm{H}_{2} \mathrm{~S}$ as a physiologic vasorelaxant: Hypertension in mice with deletion of cystathionine gamma-lyase. Science 2008, 322, 587-590. [CrossRef] 
16. Tseng, Y.S.; Liao, C.H.; Wu, W.B.; Ma, M.C. N-methyl-D-aspartate receptor hyperfunction contributes to D-serine-mediated renal insufficiency. Am. J. Physiol. Ren. Physiol. 2021, 320, F799-F813. [CrossRef]

17. Wang, L.; Jhee, K.H.; Hua, X.; DiBello, P.M.; Jacobsen, D.W.; Kruger, W.D. Modulation of cystathionine beta-synthase level regulates total serum homocysteine in mice. Circ. Res. 2004, 94, 1318-1324. [CrossRef]

18. Chiku, T.; Padovani, D.; Zhu, W.; Singh, S.; Vitvitsky, V.; Banerjee, R. $\mathrm{H}_{2} \mathrm{~S}$ biogenesis by human cystathionine gamma-lyase leads to the novel sulfur metabolites lanthionine and homolanthionine and is responsive to the grade of hyperhomocysteinemia. J. Biol. Chem. 2009, 284, 11601-11612. [CrossRef]

19. Tanizawa, K. Production of H2S by 3-mercaptopyruvate sulphurtransferase. J. Biochem. 2011, 149, 357-359. [CrossRef]

20. Wu, N.; Siow, Y.L.; Karmin, O. Ischemia/reperfusion reduces transcription factor Sp1-mediated cystathionine beta-synthase expression in the kidney. J. Biol. Chem. 2010, 285, 18225-18233. [CrossRef]

21. Corsello, T.; Komaravelli, N.; Casola, A. Role of Hydrogen Sulfide in NRF2- and Sirtuin-Dependent Maintenance of Cellular Redox Balance. Antioxidants 2018, 7, 129. [CrossRef]

22. Kimura, Y.; Goto, Y.; Kimura, H. Hydrogen sulfide increases glutathione production and suppresses oxidative stress in mitochondria. Antioxid. Redox Signal. 2010, 12, 1-13. [CrossRef]

23. Zitka, O.; Skalickova, S.; Gumulec, J.; Masarik, M.; Adam, V.; Hubalek, J.; Trnkova, L.; Kruseova, J.; Eckschlager, T.; Kizek, R Redox status expressed as GSH:GSSG ratio as a marker for oxidative stress in paediatric tumour patients. Oncol. Lett. 2012, 4 , 1247-1253. [CrossRef] [PubMed]

24. Lu, C.L.; Zheng, C.M.; Lu, K.C.; Liao, M.T.; Wu, K.L.; Ma, M.C. Indoxyl-Sulfate-Induced Redox Imbalance in Chronic Kidney Disease. Antioxidants 2021, 10, 936. [CrossRef] [PubMed]

25. Wu, W.; Bush, K.T.; Nigam, S.K. Key Role for the Organic Anion Transporters, OAT1 and OAT3, in the in vivo Handling of Uremic Toxins and Solutes. Sci. Rep. 2017, 7, 4939. [CrossRef] [PubMed]

26. Cheng, T.H.; Ma, M.C.; Liao, M.T.; Zheng, C.M.; Lu, K.C.; Liao, C.H.; Hou, Y.C.; Liu, W.C.; Lu, C.L. Indoxyl Sulfate, a Tubular Toxin, Contributes to the Development of Chronic Kidney Disease. Toxins 2020, 12, 684. [CrossRef] [PubMed]

27. Schroeder, J.C.; Dinatale, B.C.; Murray, I.A.; Flaveny, C.A.; Liu, Q.; Laurenzana, E.M.; Lin, J.M.; Strom, S.C.; Omiecinski, C.J.; Amin, S.; et al. The uremic toxin 3-indoxyl sulfate is a potent endogenous agonist for the human aryl hydrocarbon receptor. Biochemistry 2010, 49, 393-400. [CrossRef]

28. Soshilov, A.A.; Motta, S.; Bonati, L.; Denison, M.S. Transitional States in Ligand-Dependent Transformation of the Aryl Hydrocarbon Receptor into Its DNA-Binding Form. Int. J. Mol. Sci. 2020, 21, 2474. [CrossRef]

29. Ye, W.; Chen, R.; Chen, X.; Huang, B.; Lin, R.; Xie, X.; Chen, J.; Jiang, J.; Deng, Y.; Wen, J. AhR regulates the expression of human cytochrome P450 1A1 (CYP1A1) by recruiting Sp1. FEBS J. 2019, 286, 4215-4231. [CrossRef]

30. Safe, S.; Imanirad, P.; Sreevalsan, S.; Nair, V.; Jutooru, I. Transcription factor Sp1, also known as specificity protein 1 as a therapeutic target. Expert Opin. Ther. Targets 2014, 18, 759-769. [CrossRef]

31. Chang, W.C.; Hung, J.J. Functional role of post-translational modifications of Sp1 in tumorigenesis. J. Biomed. Sci. 2012, 19, 94. [CrossRef]

32. Gutiérrez-Vázquez, C.; Quintana, F.J. Regulation of the Immune Response by the Aryl Hydrocarbon Receptor. Immunity 2018, 48, 19-33. [CrossRef] [PubMed]

33. Chuang, J.Y.; Chang, W.C.; Hung, J.J. Hydrogen peroxide induces Sp1 methylation and thereby suppresses cyclin B1 via recruitment of Suv39H1 and HDAC1 in cancer cells. Free Radic. Biol. Med. 2011, 51, 2309-2318. [CrossRef] [PubMed]

34. Ishii, I.; Akahoshi, N.; Yu, X.N.; Kobayashi, Y.; Namekata, K.; Komaki, G.; Kimura, H. Murine cystathionine gamma-lyase: Complete cDNA and genomic sequences, promoter activity, tissue distribution and developmental expression. Biochem. J. 2004, 381 Pt 1, 113-123. [CrossRef]

35. Yang, G.; Pei, Y.; Teng, H.; Cao, Q.; Wang, R. Specificity protein-1 as a critical regulator of human cystathionine gamma-lyase in smooth muscle cells. J. Biol. Chem. 2011, 286, 26450-26460. [CrossRef]

36. Ge, Y.; Jensen, T.L.; Matherly, L.H.; Taub, J.W. Synergistic regulation of human cystathionine-beta-synthase-1b promoter by transcription factors NF-YA isoforms and Sp1. Biochim. Biophys. Acta 2002, 1579, 73-80. [CrossRef]

37. Osmond, J.M.; Kanagy, N.L. Modulation of hydrogen sulfide by vascular hypoxia. Hypoxia 2014, 2, 117-126. [CrossRef] [PubMed]

38. Lu, C.L.; Teng, T.Y.; Liao, M.T.; Ma, M.C. TRPV1 Hyperfunction Contributes to Renal Inflammation in Oxalate Nephropathy. Int. J. Mol. Sci. 2021, 22, 6204. [CrossRef]

39. Kimura, H. The physiological role of hydrogen sulfide and beyond. Nitric Oxide Biol. Chem. 2014, 41, 4-10. [CrossRef] [PubMed]

40. Cao, X.; Ding, L.; Xie, Z.Z.; Yang, Y.; Whiteman, M.; Moore, P.K.; Bian, J.S. A Review of Hydrogen Sulfide Synthesis, Metabolism, and Measurement: Is Modulation of Hydrogen Sulfide a Novel Therapeutic for Cancer? Antioxid. Redox Signal. 2019, 31, 1-38. [CrossRef] [PubMed]

41. Azizi, F.; Seifi, B.; Kadkhodaee, M.; Ahghari, P. Administration of hydrogen sulfide protects ischemia reperfusion-induced acute kidney injury by reducing the oxidative stress. Ir. J. Med. Sci. (1971-) 2016, 185, 649-654. [CrossRef] [PubMed]

42. Weber, G.J.; Pushpakumar, S.B.; Sen, U. Hydrogen sulfide alleviates hypertensive kidney dysfunction through an epigenetic mechanism. Am. J. Physiol.-Heart Circ. Physiol. 2017, 312, H874-H885. [CrossRef] [PubMed]

43. Dugbartey, G.J. $\mathrm{H}_{2} \mathrm{~S}$ as a possible therapeutic alternative for the treatment of hypertensive kidney injury. Nitric Oxide 2017, 64, 52-60. [CrossRef] [PubMed] 
44. Lee, H.J.; Mariappan, M.M.; Feliers, D.; Cavaglieri, R.C.; Sataranatarajan, K.; Abboud, H.E.; Choudhury, G.G.; Kasinath, B.S. Hydrogen sulfide inhibits high glucose-induced matrix protein synthesis by activating AMP-activated protein kinase in renal epithelial cells. J. Biol. Chem. 2012, 287, 4451-4461. [CrossRef] [PubMed]

45. Song, K.; Wang, F.; Li, Q.; Shi, Y.-B.; Zheng, H.-F.; Peng, H.; Shen, H.-Y.; Liu, C.-F.; Hu, L.-F. Hydrogen sulfide inhibits the renal fibrosis of obstructive nephropathy. Kidney Int. 2014, 85, 1318-1329. [CrossRef] [PubMed]

46. Bos, E.M.; Wang, R.; Snijder, P.M.; Boersema, M.; Damman, J.; Fu, M.; Moser, J.; Hillebrands, J.L.; Ploeg, R.J.; Yang, G.; et al. Cystathionine $\gamma$-lyase protects against renal ischemia/reperfusion by modulating oxidative stress. J. Am. Soc. Nephrol. JASN 2013, 24, 759-770. [CrossRef] [PubMed]

47. Motojima, M.; Hosokawa, A.; Yamato, H.; Muraki, T.; Yoshioka, T. Uremic toxins of organic anions up-regulate PAI-1 expression by induction of NF-kappaB and free radical in proximal tubular cells. Kidney Int. 2003, 63, 1671-1680. [CrossRef] [PubMed]

48. Bolati, D.; Shimizu, H.; Yisireyili, M.; Nishijima, F.; Niwa, T. Indoxyl sulfate, a uremic toxin, downregulates renal expression of Nrf2 through activation of NF-kB. BMC Nephrol. 2013, 14, 56. [CrossRef] [PubMed]

49. Edamatsu, T.; Fujieda, A.; Itoh, Y. Phenyl sulfate, indoxyl sulfate and p-cresyl sulfate decrease glutathione level to render cells vulnerable to oxidative stress in renal tubular cells. PLoS ONE 2018, 13, e0193342. [CrossRef] [PubMed]

50. Fujita, H.; Fujishima, H.; Chida, S.; Takahashi, K.; Qi, Z.; Kanetsuna, Y.; Breyer, M.D.; Harris, R.C.; Yamada, Y.; Takahashi, T. Reduction of Renal Superoxide Dismutase in Progressive Diabetic Nephropathy. J. Am. Soc. Nephrol. 2009, 20, 1303-1313. [CrossRef] [PubMed]

51. Whiteman, M.; Armstrong, J.S.; Chu, S.H.; Jia-Ling, S.; Wong, B.S.; Cheung, N.S.; Halliwell, B.; Moore, P.K. The novel neuromodulator hydrogen sulfide: An endogenous peroxynitrite 'scavenger'? J. Neurochem. 2004, 90, 765-768. [CrossRef] [PubMed]

52. Geng, B.; Chang, L.; Pan, C.; Qi, Y.; Zhao, J.; Pang, Y.; Du, J.; Tang, C. Endogenous hydrogen sulfide regulation of myocardial injury induced by isoproterenol. Biochem. Biophys. Res. Commun. 2004, 318, 756-763. [CrossRef]

53. Deguchi, T.; Kusuhara, H.; Takadate, A.; Endou, H.; Otagiri, M.; Sugiyama, Y. Characterization of uremic toxin transport by organic anion transporters in the kidney. Kidney Int. 2004, 65, 162-174. [CrossRef] [PubMed]

54. Edamatsu, T.; Fujieda, A.; Ezawa, A.; Itoh, Y. Classification of Five Uremic Solutes according to Their Effects on Renal Tubular Cells. Int. J. Nephrol. 2014, 2014, 512178. [CrossRef] 